\title{
PENGARUH KETEPATAN TERAPI DAN KEPATUHAN \\ TERHADAP HASIL TERAPI HIPERTENSI \\ DI POLIKLINIK PENYAKIT DALAM RSUP Dr. SARDJITO YOGYAKARTA
}

\author{
Adam M. Ramadhan \\ Laboratorium Penelitian dan Pengembangan FARMAKA TROPIS Fakultas Farmasi \\ Universitas Mulawarman, Samarinda, Kalimantan Timur \\ email: adam@farmasi.unmul.ac.id
}

\begin{abstract}
Hypertension is considered as one of the leading causes of death. Complication in blood tissue that is caused by hypertension and that is becoming the leading cause of death might include several diseases such as coronary artery disease (CAD), hearth attack, and stroke and kidney failure. The therapy of antihypertensive drug either in monotherapy or in combination therapy plays a very essential role for patients in which the therapy in this case must be given in consideration of the blood pressure and possibility of complication. This research is aimed to observe a description of antihypertensive drug treatment in policlinic of internal disease of RSUP Dr, Sardjito Yogyakarta, accurate treatment and treatment result and effect of medication adherence in decreasing blood pressure. This research is performed using a design of observational study supported by data prospectively taken in order to observe the accurate treatment and medication adherence of the hypertensive patient. The assessment for the therapy achievement was performed using The Seventh Report of Joint National Committee (JNC VII) on Detection, Evaluation, and Treatment of High Blood Pressure in 2003, meanwhile, the assessment for medication adherence was done by using questionnaire of new 8-item self report Morisky Medication Adherence Scale (MMAS). Based on the research, it is found that the antihypertensive drug could be in monotherapy and in combination therapy. The use of monotherapy was at (20\%) in which it was mostly dominated by CCB category at (8\%), while the use of combination therapy was at (80\%) mostly dominated by the category of ARB and CCB, namely at (55\%). Of 100 out-patients including the inclusion criteria, it was (93\%) of them that had the accurate treatment of antihypertension and (7\%) of them that did not get the accurate treatment of antihypertension. Again, it was at (91\%) that had the accurate dosage of antihypertension and (9\%) had no the accurate dosage of antihypertension. In the assessment of blood pressure, the number of the patients obtaining (the accurate medicine and dosage) with the blood pressure that could achieve the target of therapy was at (68\%) and (68\%). On the other hand, the number of the patients obtaining (the accurate medicine and dosage) but with the blood pressure not achieving the target of therapy was at $(25 \%)$ and (23\%). Furthermore, those obtaining (inaccurate medication and dosage) with the achievement of the blood pressure to the target of the therapy was at (6\%) and $(6 \%)$. It was only (1\%) and (3\%) for the patients not obtaining (inaccurate medication and dosage), not achieving the target of the therapy. Based on the medication adherence of patients in taking antihypertensive drug was at (50\%) with a high level of adherence, $(41 \%)$ with medium level and $(9 \%)$ with low level. From the test of chi-square analysis and from the significant level of 0,002 $(p<0,05)$ it is found a significant difference between adherence and the result of the decrease of blood pressure. Thus, it can be concluded that a high adherence can decrease the blood pressure.
\end{abstract}

Keywords: Hypertension, Accurate Treatment, Adherence 


\section{ABSTRAK}

Hipertensi merupakan salah satu penyebab kematian. Komplikasi pembuluh darah yang disebabkan hipertensi dapat menyebabkan kematian jantung koroner, infark jantung, stroke, dan gagal ginjal. Pemberian obat antihipertensi tunggal maupun kombinasi sangatlah penting bagi pasien tergantung pada tekanan darah dan ada tidaknya komplikasi. Penelitian ini bertujuan untuk melihat gambaran penggunaan obat antihipertensi di poliklinik penyakit dalam instalasi rawat jalan RSUP Dr. Sardjito Yogyakarta, ketepatan terapi dan hasil terapi serta pengaruh kepatuhan dalam menurunkan tekanan darah. Penelitian dilakukan dengan rancangan studi observasional dengan pengambilan data secara prospektif, kemudian dilakukan analisis terhadap data yang diperoleh untuk melihat ketepatan terapi dan kepatuhan pasien hipertensi. Penilaian keberhasilan terapi The Seventh Report of Joint National Committee (JNC VII) on Detection, Evaluation, and Treatment of High Blood Pressure tahun 2003, sedangkan penilaian kepatuhan menggunakan kuisoner new 8-item self report Morisky Medication Adherence Scale (MMAS). Berdasarkan penelitian, obat antihipertensi yang digunakan adalah terapi tunggal dan kombinasi. Penggunaan terapi tunggal sebesar (20\%) yang terbanyak adalah golongan CCB (8\%) sedangkan penggunaan terapi kombinasi sebesar $(80 \%)$ yang paling banyak adalah golongan ARB dengan CCB sebesar (55\%). Dari 100 pasien rawat jalan yang termasuk kriteria inklusi ada $(93 \%)$ mendapatkan tepat terapi antihipertensi, dan (7\%) mendapatkan tidak tepat terapi antihipertensi, sedangkan (91\%) mendapatkan tepat dosis antihipertensi, dan 9\% mendapatkan tidak tepat dosis antihipertensi. Penilaian tekanan darah pasien yang mendapatkan (tepat obat dan dosis) dan tekanan darahnya mencapai target terapi masing-masing sebesar (68\%) dan (68\%). Pasien yang mendapatkan (tepat obat dan dosis) tetapi tekanan darah tidak tercapai masing-masing sebesar (25\%) dan (23\%). Sedangkan pasien yang mendapatkan (tidak tepat obat dan dosis) tetapi tekanan darahnya tercapai masing-masing sebesar (6\%) dan (6\%). Pasien yang mendapatkan (tidak tepat obat dan dosis) dan tekanan darah tidak mencapai target terapi masing-masing sebesar (1\%) dan (3\%). Berdasarkan kepatuhan pasien dalam mengkonsumsi obat antihipertensi (50\%) dengan tingkat kepatuhan tinggi, (41\%) tingkat kepatuhan sedang dan (9\%) tingkat kepatuhan rendah. Dari uji analisis chi-square angka signifikansi 0,002 $(\mathrm{p}<0,05)$ didapatkan adanya perbedaan yang signifikan antara kepatuhan dengan hasil penurunan tekanan darah sehingga dapat disimpulkan bahwa kepatuhan yang tinggi dapat menurunkan tekanan darah.

Kata kunci: Hipertensi, Ketepatan Terapi, Kepatuhan

\section{PENDAHULUAN}

Hipertensi merupakan salah satu penyebab kematian. Komplikasi pembuluh darah yang disebabkan hipertensi dapat menyebabkan kematian jantung koroner, infark jantung, stroke, dan gagal ginjal. Komplikasi pada organ tubuh menyebabkan angka kematian yang tinggi. Hipertensi merupakan salah satu faktor risiko utama gangguan jantung. Selain mengakibatkan gagal jantung, hipertensi dapat berakibat gagal ginjal maupun penyakit cerebrovaskuler (Anonim, 2007).

Dalam sebuah survey yang dilakukan di tahun 2000, hipertensi didapatkan pada $28 \%$ populasi dewasa di Amerika. Berdasarkan studi Framingham 
mengenai tekanan darah pada orang lanjut usia sekitar 90\% individu ras caucasia di Amerika akan mengalami hipertensi dimasa hidupnya. Prevalensi hipertensi tersebut bervariasi dengan umur, ras, pendidikan, dan banyak variabel lainnya. Hipertensi arterial yang berkepanjangan akan merusak pembuluhpembuluh darah ginjal, jantung, dan otak serta menimbulkan peningkatan insiden gagal ginjal penyakit koroner, gagal jantung, dan stroke (Katzung, 2010).

Health People 2010 for Hypertension menganjurkan perlunya pendekatan yang lebih komprehensif dan intensif guna mencapai pengontrolan tekanan darah secara optimal. Maka untuk mencapai tujuan tersebut, diperlukan partisipasi aktif para sejawat apoteker yang melaksanakan praktek profesinya pada setiap tempat pelayanan kesehatan. Apoteker dapat bekerja sama dengan dokter dalam memberikan edukasi ke pasien mengenai hipertensi, memonitor respon pasien melalui farmasi komunitas, adherence terhadap terapi obat dan non-obat, mendeteksi dan mengenali secara dini reaksi samping, serta mencegah dan/atau memecahkan masalah yang berkaitan dengan pemberian obat (Anonim, 2007).

Skala self-report untuk menilai kepatuhan penggunaan obat antihipertensi telah dikembangkan oleh Morisky et al., (2008). Penelitian untuk menguji psikometri dan prediksi validitas dari struktur self report medication adherence diujikan pada pasien hipertensi pada tahun 2007 dan dipublikasikan Januari 2008. Self report kepatuhan penggunan obat diukur dengan new 8-item self report Morisky Medication Adherence Scale (MMAS).

Berdasarkan latar belakang diatas maka perlu dilakukan penelitian tentang pengaruh ketepatan terapi dan kepatuhan terhadap hasil terapi hipertensi di poliklinik penyakit dalam unit hipertensi instalasi rawat jalan RSUP Dr. Sardjito Yogyakarta. Penelitian ini diharapkan dapat memberikan gambaran penggunaan obat antihipertensi, ketepatan terapi hipertensi dan hasil terapi serta pengaruh kepatuhan dalam menurunkan tekanan darah.

\section{METODE PENELITIAN}

Subyek penelitian adalah semua pasien hipertensi di poliklinik penyakit dalam instalasi rawat jalan RSUP Dr. Sardjito Yogyakarta periode FebruariApril 2012 yang memenuhi kriteria inklusi.

Kriteria inklusi pasien pada penelitian ini, antara lain pasien dewasa berusia > 18 tahun, pasien laki-laki maupun perempuan, pasien hipertensi yang melakukan kontrol rutin selama 3 bulan (Februari-April 2012), terdiagnosis oleh dokter menderita prehipertensi, hipertensi tingkat 1 maupun tingkat 2 dengan atau tanpa dislipidemia dan diabetes mellitus (DM), mendapatkan obat antihipertensi dengan regimen golongan obat yang tidak berubah selama 3 bulan penelitian. Sedangkan kriteria eksklusi pasien, antara lain buta huruf, hamil, pasien dengan cronic kidney disease dan pasien yang melakukan hemodialisa.

Penelitian yang dilakukan merupakan penelitian observasional (non eksperimental) dengan pengambilan data pasien secara prospektif. Kemudian dilakukan analisis data untuk mengetahui gambaran penggunaan obat antihipertensi, ketepatan terapi (tepat obat dan dosis) hipertensi, hasil terapi pada pasien hipertensi dan pengaruh kepatuhan terhadap hasil terapi hipertensi. Penilaian ketepatan terapi berdasarkan antihipertensi berdasarkan JNC VII tahun 2003, sedangkan penilaian kepatuhan menggunakan kuisoner Morisky Medication Adherence Scale (MMAS).

\section{HASIL DAN PEMBAHASAN}

Pada penelitian ini, obat antihipertensi yang digunakan adalah terapi tunggal dan kombinasi. Untuk 
melihat gambaran penggunaan obat antihipertensi dapat dilihat pada Tabel 1.

Tabel 1 menunjukkan bahwa penggunaan obat antihipertensi di poliklinik penyakit dalam RSUP Dr. Sardjito adalah obat antihipertensi tunggal sebesar $(20 \%)$ dan obat antihipertensi kombinasi adalah (80\%).
Tabel 2 menunjukkan bahwa penggunaan terapi tunggal yang terbanyak adalah golongan CCB (8\%) sedangkan untuk terapi kombinasi yang paling banyak digunakan golongan ARB dengan CCB sebesar (55\%).

Tabel 1 Profil Terapi Obat Antihipertensi Tunggal dan Kombinasi di Poliklinik Penyakit Dalam Instalasi Rawat Jalan RSUP Dr. Sardjito Yogyakarta Periode FebruariApril 2012

\begin{tabular}{|c|c|c|}
\hline Terapi Obat Antihipertensi & Jumlah Pasien $(\mathrm{n}=100)$ & Persentase $(\%)$ \\
\hline Tunggal & 20 & 20 \\
\hline Kombinasi & 80 & 80 \\
\hline Total & 100 & 100 \\
\hline
\end{tabular}

Tabel 2 Profil Terapi Obat Antihipertensi Pada Pasien Hipertensi di Poliklinik Penyakit Dalam Instalasi Rawat Jalan RSUP Dr. Sardjito Yogyakarta Periode FebruariApril 2012

\begin{tabular}{|c|c|c|c|c|}
\hline $\begin{array}{c}\text { Terapi obat } \\
\text { antihipertensi }\end{array}$ & $\begin{array}{c}\text { Golongan obat } \\
\text { antihipertensi }\end{array}$ & Nama Generik & $\begin{array}{c}\text { Jumlah } \\
\text { Pasien }\end{array}$ & $\begin{array}{c}\text { Persentase (\%) } \\
(\mathrm{n}=100)\end{array}$ \\
\hline Tunggal & CCB & Amlodipin & 8 & 8 \\
\hline Kombinasi & ARB+CCB & Valsartan-Amlodipin & 55 & 55 \\
\hline
\end{tabular}

Tabel 3 Ketidaktepatan Obat Antihipertensi Pada Pasien Hipertensi di Poliklinik Penyakit Dalam Instalasi Rawat Jalan RSUP Dr. Sardjito Yogyakarta Periode FebruariApril 2012

\begin{tabular}{|c|c|c|c|c|c|c|}
\hline \multirow[t]{2}{*}{$\begin{array}{l}\text { No } \\
\text { pasien }\end{array}$} & \multirow[t]{2}{*}{$\begin{array}{l}\text { Diagnosa } \\
\text { Terakhir }\end{array}$} & \multirow[t]{2}{*}{$\begin{array}{l}\text { Obat yang } \\
\text { digunakan }\end{array}$} & \multicolumn{3}{|c|}{$\begin{array}{l}\text { Tekanan Darah }(\mathrm{mmHg}) / \\
\text { pada bulan }\end{array}$} & \multirow[t]{2}{*}{ Jenis ketidaktepatan } \\
\hline & & & Februari & Maret & April & \\
\hline 18 & $\begin{array}{l}\text { HT stage II, } \\
\text { Dislipidemia }\end{array}$ & $\begin{array}{l}\text { Hexavask, } \\
\text { simvastatin }\end{array}$ & $140 / 90$ & $110 / 70$ & $130 / 80$ & $\begin{array}{l}\text { Obat antihipertensi } \\
\text { tunggal }\end{array}$ \\
\hline 30 & $\begin{array}{l}\text { HT dalam } \\
\text { terapi, } \\
\text { Dislipidemia }\end{array}$ & $\begin{array}{l}\text { Irtan, adalat } \\
\text { oros, HCT }\end{array}$ & $140 / 90$ & $140 / 90$ & $130 / 80$ & $\begin{array}{l}\text { Penggunaan HCT } \\
\text { pada penyakit } \\
\text { dislipidemia }\end{array}$ \\
\hline 37 & $\begin{array}{l}\text { HT stage II, } \\
\text { Dislipidemia }\end{array}$ & $\begin{array}{l}\text { Adalat oros, } \\
\text { simvastatin }\end{array}$ & $160 / 90$ & $130 / 80$ & $130 / 80$ & $\begin{array}{l}\text { Obat antihipertensi } \\
\text { tunggal }\end{array}$ \\
\hline 47 & $\begin{array}{l}\text { HT stage II, } \\
\text { Dislipidemia }\end{array}$ & $\begin{array}{l}\text { Valsartan, } \\
\text { HCT }\end{array}$ & $140 / 80$ & $130 / 90$ & $140 / 90$ & $\begin{array}{l}\text { Penggunaan HCT } \\
\text { pada penyakit } \\
\text { dislipidemia }\end{array}$ \\
\hline 50 & $\begin{array}{l}\text { HT stage II } \\
\text { dalam terapi, } \\
\text { Dislipidemia }\end{array}$ & $\begin{array}{l}\text { Valsartan, } \\
\text { Hexavask, } \\
\text { HCT }\end{array}$ & 130/80 & $120 / 80$ & 130/80 & $\begin{array}{l}\text { Penggunaan HCT } \\
\text { pada penyakit } \\
\text { dislipidemia }\end{array}$ \\
\hline 52 & $\begin{array}{l}\text { HT stage II, } \\
\text { Dislipidemia }\end{array}$ & $\begin{array}{l}\text { Irtan, } \\
\text { gemfibrozil }\end{array}$ & $140 / 100$ & $110 / 70$ & $130 / 90$ & $\begin{array}{l}\text { Obat antihipertensi } \\
\text { tunggal }\end{array}$ \\
\hline 62 & $\begin{array}{l}\text { HT dalam } \\
\text { terapi, } \\
\text { Dislipidemia }\end{array}$ & $\begin{array}{l}\text { Valsartan, } \\
\text { HCT } \\
\text { Simvastatin }\end{array}$ & $120 / 80$ & $130 / 90$ & $120 / 70$ & $\begin{array}{l}\text { Penggunaan } \mathrm{HCT} \\
\text { pada penyakit } \\
\text { dislipidemia }\end{array}$ \\
\hline
\end{tabular}


Tabel 4 Ketidaktepatan Dosis Antihipertensi Dibawah Dosis Minimal Perhari (under dose) Pada Pasien Hipertensi di Poliklinik Penyakit Dalam Instalasi Rawat Jalan RSUP Dr. Sardjito Yogyakarta Periode Februari-April 2012

\begin{tabular}{|c|c|c|c|c|c|c|}
\hline \multirow{2}{*}{$\begin{array}{c}\text { No } \\
\text { pasien }\end{array}$} & \multicolumn{2}{|c|}{$\begin{array}{c}\text { Tekanan Darah }(\mathrm{mmHg}) / \\
\text { pada bulan }\end{array}$} & Obat & $\begin{array}{c}\text { Dosis yang } \\
\text { diberikan } \\
\text { (mg/hari) }\end{array}$ & $\begin{array}{c}* \text { Kisaran dosis } \\
\text { (mg/hari) }\end{array}$ \\
\cline { 2 - 4 } & Februari & Maret & April & & $5 / 5$ & $\begin{array}{c}2.5 / 10,5 / 10, \\
5 / 20,10 / 20\end{array}$ \\
\hline 66 & $170 / 100$ & $110 / 80$ & $130 / 80$ & $\begin{array}{c}\text { Amdixal- } \\
\text { Noperten }\end{array}$ & & $10-40$ \\
\hline 86 & $120 / 80$ & $130 / 80$ & $120 / 80$ & Noperten & 5 & $10-40$ \\
\hline 89 & $120 / 80$ & $110 / 70$ & $130 / 80$ & Noperten & 5 & $10-40$ \\
\hline 97 & $140 / 90$ & $140 / 90$ & $130 / 80$ & Noperten & 5 & $10-40$ \\
\hline 100 & $130 / 80$ & $130 / 80$ & $150 / 80$ & Noperten & 5 & 5 \\
\hline
\end{tabular}

Keterangan :

(*Berdasarkan algoritma terapi hipertensi dari JNC VII Express : The Seventh Report of the Joint National Committee on Prevention, Detection, Evalution and Treatment of High Blood Presure, 2003)

Tabel 5 Ketidaktepatan Dosis Antihipertensi Diatas Dosis Minimal Perhari (over dose) Pada Pasien Hipertensi di Poliklinik Penyakit Dalam Instalasi Rawat Jalan RSUP Dr. Sardjito Yogyakarta Periode Februari-April 2012

\begin{tabular}{|c|c|c|c|c|c|c|}
\hline \multirow[t]{2}{*}{$\begin{array}{c}\text { No } \\
\text { pasien }\end{array}$} & \multicolumn{3}{|c|}{$\begin{array}{c}\text { Tekanan Darah }(\mathrm{mmHg}) / \\
\text { pada bulan }\end{array}$} & \multirow[t]{2}{*}{ Obat } & \multirow{2}{*}{$\begin{array}{c}\text { Dosis yang } \\
\text { diberikan } \\
\text { (mg/hari) }\end{array}$} & \multirow[t]{2}{*}{$\begin{array}{c}{ }^{*} \text { Kisaran dosis } \\
\text { (mg/hari) }\end{array}$} \\
\hline & Februari & Maret & April & & & \\
\hline 8 & $110 / 70$ & $130 / 90$ & $110 / 70$ & $\begin{array}{l}\text { Noperten- } \\
\text { HCT }\end{array}$ & $10 / 25$ & $\begin{array}{c}10 / 12.5 \\
20 / 12.5,20 / 25\end{array}$ \\
\hline 47 & $140 / 80$ & $130 / 90$ & $140 / 90$ & $\begin{array}{l}\text { Valsartan- } \\
\text { HCT }\end{array}$ & $80 / 25$ & $\begin{array}{c}80 / 12.5 \\
160 / 12.5 \\
160 / 25\end{array}$ \\
\hline 62 & $120 / 90$ & $130 / 90$ & $120 / 70$ & $\begin{array}{l}\text { Valsartan- } \\
\text { HCT }\end{array}$ & $80 / 25$ & $\begin{array}{c}80 / 12.5 \\
160 / 12.5 \\
160 / 25\end{array}$ \\
\hline 67 & $110 / 70$ & $120 / 70$ & $140 / 100$ & $\begin{array}{l}\text { Valsartan- } \\
\text { HCT }\end{array}$ & $80 / 25$ & $\begin{array}{c}80 / 12.5 \\
160 / 12.5 \\
160 / 25\end{array}$ \\
\hline
\end{tabular}

Keterangan :

(*Berdasarkan algoritma terapi hipertensi dari JNC VII Express : The Seventh Report of the Joint National Committee on Prevention, Detection, Evalution and Treatment of High Blood Presure, 2003)

Tabel 3 menunjukkan bahwa ketepatan terapi pemilihan obat antihipertensi $(93 \%)$ mendapatkan tepat obat antihipertensi, dan $(7 \%)$ tidak tepat obat antihipertensi. Ketidaktepatan obat disebabkan karena pemberian terapi tunggal pada pasien yang mengalami hipertensi stage II. JNC VII menyarankan penggunaan dua macam obat atau lebih untuk mengendalikan tekanan tekanan darah hipertensi yang memasuki stage II.
Selain itu penggunaan diuretik thiazid pada pasien hipertensi dengan dislipidemia masih kontroversial karena efek sampingnya yang dapat meningkatkan kadar kolesterol total dan HDL dalam darah sehingga lebih baik dihindari selagi masih terdapat golongan lain yang dapat digunakan (Weir dan Moser, 2000). Diuretik meningkatkan asam urat serum, pencetus gout, meningkatkan glukosa darah, low density 
lipoprotein cholesterol (LDL) dan insulin plasma. Efek tersebut kecil pada pemakaian jangka panjang dengan menggunakan dosis rendah (McPhee dan Massie, 2005; Dickerson dan Gibson, 2005). Diuretik meningkatkan kadar trigliserida plasma dan LDL, ditemukan pada penelitian-penelitian jangka waktu satu tahun atau lebih pendek (Hoffman dan Carruters, 2000). Dislipidemia merupakan salah satu faktor resiko terjadinya hipertensi dan penyakit kardiovaskuler lainnya seperti atherosclerosis dan penyakit jantung koroner (Saseen dan Carter, 2009) mekanisme terjadinya hipertensi pada pasien dislipidemia dapat disebabkan oleh adanya disfungsi endotial pembuluh darah karena penumpukan lipid (Halperin dkk., 2006).

Tabel 4 dan tabel 5 menunjukkan bahwa (91\%) mendapatkan tepat dosis antihipertensi, dan (9\%) tidak tepat dosis antihipertensi. Ketidaktepatan dosis disebabkan karena dosis yang diberikan dibawah dosis perhari (tabel 4) dan kombinasi dosis yang diberikan terlalu besar (tabel 5). Menurut JNC VII dalam pemberian terapi tunggal maupun kombinasi ada standar dengan dosis yang telah ditentukan mengacu pada algoritma terapi hipertensi.

Tabel 6 Tekanan Darah yang Tepat Target Pada Pasien Hipertensi di Poliklinik Penyakit Dalam Instalasi Rawat Jalan RSUP Dr. Sardjito Yogyakarta Periode FebruariApril 2012

\begin{tabular}{|c|c|c|c|c|}
\hline Target Tekanan & \multicolumn{4}{|c|}{ Ketepatan Terapi $(\mathrm{n}=100)$} \\
\cline { 2 - 5 } Darah $(\mathrm{mmHH})$ & Tepat Obat & Tidak Tepat Obat & Tepat Dosis & Tidak Tepat Dosis \\
\hline Tercapai & 68 orang & 6 orang & 68 orang & 6 orang \\
$(<140 / 90)$ & $(68 \%)$ & $(6 \%)$ & $(68 \%)$ & $(6 \%)$ \\
\hline Tidak tercapai & 25 orang & 1 orang & 23 orang & 3 orang \\
$(>140 / 90)$ & $(25 \%)$ & $(1 \%)$ & $(23 \%)$ & $(3 \%)$ \\
\hline
\end{tabular}

Tabel 7 Gambaran Tingkat Kepatuhan Pasien Hipertensi di Poliklinik Penyakit Dalam Instalasi Rawat Jalan RSUP Dr. Sardjito Yogyakarta Periode Februari-April 2012

\begin{tabular}{|c|c|}
\hline Tingkat Kepatuhan & Persentase $(\%)(\mathrm{n}=100)$ \\
\hline Rendah & 9 \\
\hline Sedang & 41 \\
\hline Tinggi & 50 \\
\hline
\end{tabular}

Tabel 8 Alasan ketidakpatuhan yang paling banyak pada pasien hipertensi yang tergolong tingkat kepatuhan rendah berdasarkan kuisoner MMAS

\begin{tabular}{|l|l|c|}
\hline No & Alasan ketidakpatuhan & Jumlah Poin \\
\hline 1 & Lupa & 7 \\
\hline 2 & Sengaja tidak minum & 9 \\
\hline
\end{tabular}

Tabel 6 menunjukkan bahwa penilaian tekanan darah pasien yang mendapatkan tepat obat dan tekanan darahnya mencapai target terapi sebesar $(68 \%)$. Pasien yang mendapatkan tepat obat tetapi tekanan darah tidak tercapai sebesar $(25 \%)$. Sedangkan pasien yang mendapatkan tidak tepat obat tetapi tekanan darahnya tercapai sebesar $(6 \%)$. Pasien yang mendapatkan tidak tepat obat dan tekanan darah tidak mencapai target terapi sebesar (1\%). Pada pasien yang mendapatkan tepat dosis dan tekanan darahnya mencapai target terapi sebesar 
(68\%). Pasien yang mendapatkan tepat obat tetapi tekanan darah tidak tercapai sebesar $(23 \%)$. Sedangkan pasien yang mendapatkan tidak tepat obat tetapi tekanan darahnya tercapai sebesar $(6 \%)$. Pasien yang mendapatkan tidak tepat dosis dan tekanan darah tidak mencapai target terapi sebesar (3\%). Pasien yang mendapatkan ketepatan terapi (tepat obat dan tepat dosis) tetapi tekanan darah tidak mencapai target disebabkan oleh pasien tidak patuh dalam mengkonsumsi obat anthipertensi. Sedangkan pasien yang mendapatkan terapi yang tidak tepat (tidak tepat obat dan tidak tepat dosis) tekanan darahnya mencapai target disebabkan adanya bias dalam mengukur tekanan darah. Secara teori penggunaan antihipertensi yang tidak tepat maka tekanan darah tidak akan mencapai target. Bias tekanan darah mungkin dapat terjadi dan dapat mempengaruhi ketidakberhasilan pencapaian sasaran terapi tekanan darah ataupun keberhasilan pencapaian sasaran terapi karena teknik pengukuran tekanan darah yang tepat sangat dibutuhkan untuk mendapatkan hasil yang valid.

Tabel 7 menunjukkan bahwa penilaian kepatuhan pasien dalam terapi antihipertensi menggunakan kuisoner Morisky Medication Adherence Scale (MMAS). Dari 100 pasien pada penelitian ini didapatkan bahwa pasien tingkat kepatuhannya tinggi sebesar (50\%), (41\%) kepatuhannya sedang dan (9\%) dengan tingkat kepatuhan rendah.

Setelah dikelompokkan ada 9 pasien yang termasuk tingkat kepatuhan rendah (tabel 7), dari 9 pasien tersebut menunjukkan bahwa ada dua faktor alasan ketidakpatuhan pasien dalam mengkonsumsi obat antihipertensi yaitu pasien sering lupa minum obat dan sengaja tidak minum obat karena adanya pemahaman yang salah terhadap penyakit yang dialami mereka (tabel 8). Pasien yang tidak patuh minum obat beranggapan bahwa ketika tekanan darah telah turun maka beranggapan bahwa penyakitnya sudah sembuh sehingga tidak perlu minum obat lagi. Apabila tekanan darah pasien naik maka pasien akan minum obat antihipertensi tersebut. Selain itu ketidakpatuhan dalam mengkonsumsi obat diakibatkan karena ketidakfahaman pasien ketika tekanan darah tidak mencapai tekanan darah $<140 / 90 \mathrm{mmHg}$ pada pasien hipertensi non diabetes mellitus dan < 130/80 $\mathrm{mmHg}$ pada pasien hipertensi dengan diabetes mellitus.

Adapun pengaruh kepatuhan terhadap hasil terapi dilakukan uji korelasi. Dalam hal ini yang dikorelasikan adalah katagori Morisky Medication Adherence Scale (MMAS) dengan tekanan darah. Setelah dianalisis dengan uji chi-square angka signifikansi $0,002$ ( $\mathrm{p}<0,05)$ didapatkan adanya perbedaan yang signifikan antara kepatuhan dengan hasil penurunan tekanan darah sehingga dapat disimpulkan bahwa kepatuhan tinggi dapat menurunkan tekanan darah.

\section{KESIMPULAN}

Dari hasil penelitan ini dapat disimpulkan bahwa dari 100 pasien rawat jalan yang memenuhi kriteria inklusi:

a. Obat antihipertensi yang digunakan adalah terapi tunggal dan kombinasi. Penggunaan terapi tunggal sebesar (20\%) yang terbanyak adalah golongan CCB $(8 \%)$ sedangkan untuk terapi kombinasi sebesar $(80 \%)$ yang paling banyak digunakan golongan ARB dengan CCB sebesar (55\%).

b. Berdasarkan ketepatan terapi pemilihan obat antihipertensi diketahui bahwa (93\%) mendapatkan tepat terapi antihipertensi, dan (7\%) tidak tepat terapi antihipertensi. Sedangkan $(91 \%)$ mendapatkan tepat dosis antihipertensi, dan (9\%) tidak tepat dosis antihipertensi.

c. Berdasarkan pencapaian target terapi hipertensi diketahui bahwa pasien yang mendapatkan (tepat obat dan dosis) dan tekanan darahnya mencapai 
target terapi masing-masing sebesar (68\%) dan (68\%). Pasien yang mendapatkan (tepat obat dan dosis) tetapi tekanan darah tidak tercapai masing-masing sebesar (25\%) dan (23\%). Sedangkan pasien yang mendapatkan (tidak tepat obat dan dosis) tetapi tekanan darahnya tercapai masing-masing sebesar (6\%) dan (6\%). Pasien yang mendapatkan (tidak tepat obat dan dosis) dan tekanan darah tidak mencapai target terapi masing-masing sebesar (1\%) dan $(3 \%)$.

d. Berdasarkan kepatuhan pasien dalam mengkonsumsi obat antihipertensi, $(50 \%)$ dengan tingkat kepatuhan tinggi, $(41 \%)$ tingkat kepatuhan sedang dan (9\%) tingkat kepatuhan rendah. Dari uji analisis chi-square angka signifikansi $0,002 \quad(\mathrm{p}<0,05)$ didapatkan adanya perbedaan signifikan antara kepatuhan dengan hasil penurunan tekanan darah sehingga dapat disimpulkan kepatuhan yang tinggi dapat menurunkan tekanan darah.

\section{DAFTAR PUSTAKA}

1. Anonim, 2007, Pharmaceutical Care untuk Penyakit Hipertensi, Direktorat Bina Farmasi Komunitas dan Klinik, Depkes RI, Jakarta, hal 12-16.

2. Chobanian, A.V., Bakris, G.L., Black, H.R., Cushman, W.L., Green 1.A., izzo, J.1., Jones, D.W., Materson, B.J., Oparil, S, dan Wright, J.T., 2003. JNC VII Express: The Seventh Report of the Joint National Committee on Prevention, Detection, Evalution and Treatment of High Blood Presure, U.S. Deparment of Health and Human Services, pp 12-33.

3. DickEreson, L.M., Gibson, M.V., 2005, Management of Hypertension in older person, Am Fam Phys, $71: 3$, 469-475, www.aafp.org/afp.
4. Halperin, R.O., Sesso, H.D., JingMa, Buring, J.E., Stampfer, M.J., and Gaziano, J.M., 2006, Dyslipidemia and the Risk of Incident Hypertension in Men, diakses 10 Juni 2012, http://hyper.ahajournals.org/cgi/cont ent/full/47/1/45.

5. Hoffman, B.B., Carruthers, S.G., 2000, Cardiovaskuler Disorder, Hypertension in Carruters, S.G., McGraw-Hill, Chapter : 1.1-5.

6. Katzung., G., Bertram., 2010., Farmakologi Dasar dan Klinik, Edisi 10, Jakarta : Penerbit Buku Kedokteran EGC, hal. 161-162.

7. Morisky, D.E., Ang A, KrouselWood, M.A., Ward H, 2008, Predictive Validity of A Medication Adherence Measure in an Outpatient Setting, J. Health-Syst. Pharm, 10:348-54.

8. McPhee, S.J., Massie, B.M., 2005, Systemic Hypertension, in Tierne, L.M., McPhee, S.J., Papadakis, M.A., Current Medical Diagnosis and Disease Management, McGraw-Hill, 412.

9. Sakthong $\mathrm{P}$, Chabunthom R, Charoenvisuthiwongs R (2009) Psychometric properties of the Thai version of the 8-item Morisky Medication Adherence Scale in patients with type 2 diabetes. Ann Pharmacother. May;43(5):950-7.

10. Saseen, J.J., and Carter, B.L., 2009, Essential Hypertension, in : Koda Kimble, M.A., Young, L.Y., Kradjan, W.A., Guglielmo, B.J., Alldredge, B.K., dan Corelli, R.L., (eds) : Applied Therapeutics : The Clinical Use of Drugs, Eight Edition, New York : Lippincot Williams \& Wilkin, Chapter : 14.1-43.

11. Weir, M. R., and Moser, M., 2000, Diuretik and $\beta$ bloker: is the there a risk for dyslipidemia? diakses 17 mei 2010, $\quad$ http://www.medscape.view article/40908 